\title{
Radical scavenger competition of alizarin and curcumin: a mechanistic DFT study on antioxidant activity
}

\author{
Malek Sadatsharifi ${ }^{1} \cdot$ Mihály Purgel $^{2}$ (D) \\ Received: 17 November 2020 / Accepted: 25 April 2021 / Published online: 13 May 2021 \\ (C) The Author(s) 2021
}

\begin{abstract}
In vivo hydroxyl, peroxyl, and superoxide free radicals caused by oxidative stress can be toxic to molecules that are essential for the human body. However, there are natural compounds that can decrease the amount of these harmful species. In this work, we are focusing on two well-known compounds, alizarin (red) and curcumin, to study their interactions with these small radicals for a comparison between a rigid and a flexible structure. We made a mechanistic study and found the major and minor degradation products of curcumin as well as the autoxidation products of it based on a wide range of literature. We found several more favored pathways than those that were previously proposed. On the contrary, for degradation/oxidation of alizarin, only a few proposed mechanisms can be found which were performed in specific conditions. Our calculations predicted some favored rearrangements for the alizarin by peroxyl and superoxide radicals.
\end{abstract}

Keywords Epoxide $\cdot$ Mechanism $\cdot$ Peroxo bond $\cdot$ Cleavage $\cdot$ Degradation $\cdot$ Autoxidation

\section{Introduction}

During the last decade, much research has been conducted examining the biological effects of free radicals [1-6] and antioxidants [7-9]. Free radicals are dangerous for living cells, and therefore compounds that can scavenge them are an interesting subject for experimentation [10]. Diseases can be caused by radicals, but nowadays researchers are focusing more on natural compounds, mainly phenolics, as potential therapeutic agents to block the metabolic disorders (diabetes, cancer, etc.) of free radicals [11-13]. In the present work, we are focusing on alizarin and curcumin which are biologically active $[14,15]$ and on their interactions with potentially toxic molecules such as hydroxyl, peroxyl, and superoxide radicals [16-18]. These are mainly defined as reduced oxygen agents but in general; they can be categorized as reactive oxygen species (ROS). These are highly reactive regarding membrane lipids, protein, and DNA, and in general, they can damage cellular components and are probably responsible for stress

Mihály Purgel

purgel.mihaly@science.unideb.hu

1 University of Debrecen, Egyetem tér 1, Debrecen H-4032, Hungary

2 Department of Physical Chemistry, University of Debrecen, Egyetem tér 1, Debrecen H-4032, Hungary injuries and conditions as well $[19,20]$. Both alizarin and curcumin are the subjects of substantial literature in many different areas. Their usage as antioxidants has been actively explored during the last few decades; however, mechanisms and detailed effects are still not fully understood [21, 22]. Alizarin (1,2-dihydroxy-9,10-anthraquinone) can be isolated from the roots of the common madder (Rubia tinctorum L.) [23]. It is used as a Japanese food colorant, and its carcinogenic activity was proven in rats [24]. Clinical applications (bio-labeling, etc.) are typical research topics involving alizarin (AR) compounds as well [24, 25]. AR is a well-known $\mathrm{pH}$ indicator due to the changes in its color in terms of (de)protonation of the $-\mathrm{OH}$ group at the $\mathrm{C} 2$ position (see Scheme 1). It is a quinone, and quinones are known as radical competitors that can stabilize radical forms [26]. Benzoquinone can uptake hydrogen atoms, but it is unable to lose hydrogen from its aromatic ring. Alizarin, however, has an extended ability to form a radical not only by uptaking hydrogen atoms but also by losing hydrogen from hydroxyl groups. Curcumin $\{\mathrm{CM}$; (1E,6E)-1,7-bis(4-hydroxy-3methoxyphenyl)hepta-1,6-diene-3,5-dione \} exists in two tautomeric forms (see Scheme 1) and has been isolated from Curcuma longa and found to be a promising natural antioxidant; therefore, it is widely investigated by researchers. It is a compound of turmeric that has been used for centuries as a natural and traditional medicine in Asia for various diseases 

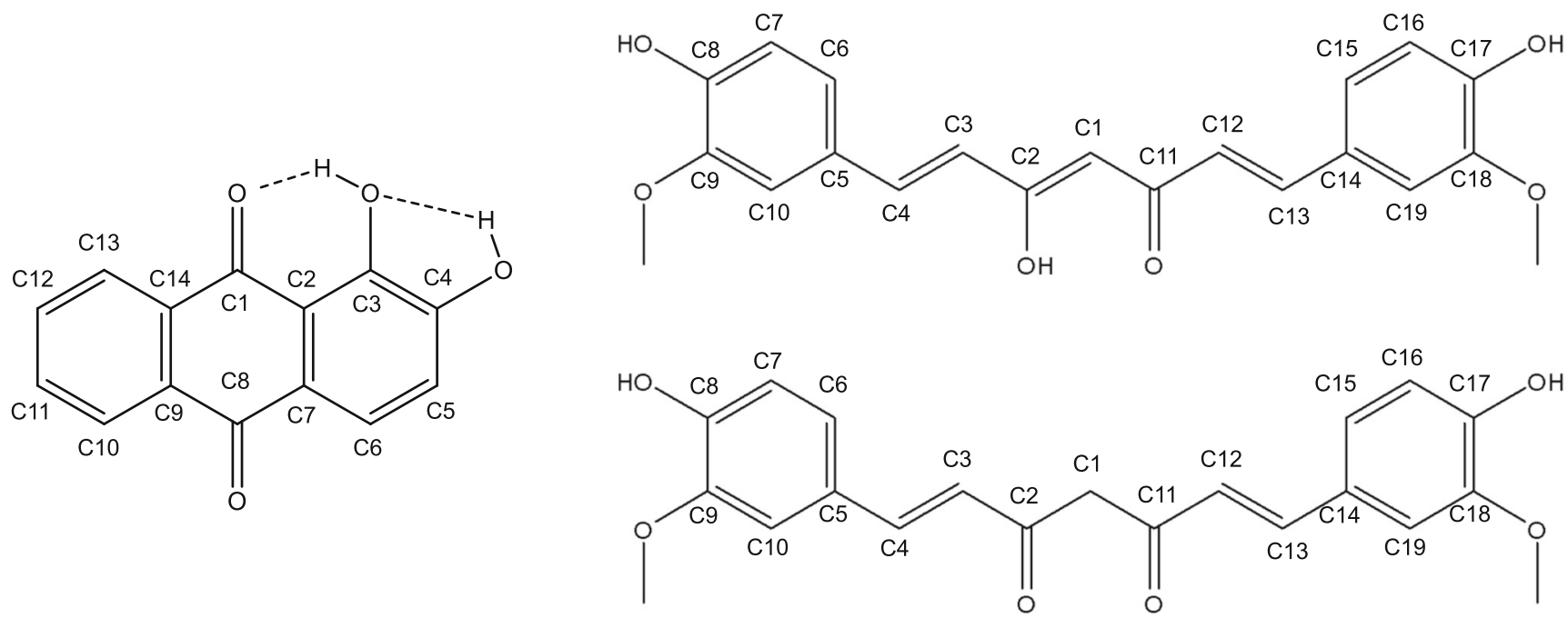

Scheme 1 Structures and numbering of the most stable form of alizarin and curcumin tautomers

(liver ailments, parasitic infections, skin diseases, inflammations, and flu symptoms). In recent years, curcumin has been studied as a therapeutic agent and as a cell protector against Alzheimer's disease [27-30]. Moreover, the anticancer effect of curcumin has been shown as a pro-oxidant by generating reactive oxidant species (ROS) [31], and its anticarcinogenic effect concerning concentration dependence has been proven as well [32].

Besides, the decomposition of curcumin has been studied in physiological conditions by Wang et al., and trans-6-(4'-hydroxy3'-methoxyphenyl)-2,4-dioxo-5-hexenal was found as major while $o$-vanillin, ferulic acid, and feruloyl methane were identified as minor degradation products [33]. Masuda et al. found, however, that degradation processes in nonpolar medium went through radical formation, in which oxygen molecule coordinated to the carbon minor and carbon major radical species. From those adducts, cyclizations were proposed resulting in four centered $\mathrm{CCOO}$ radical species, and depending on the position of the cyclic unit, vanillin and trans-6-(4'-hydroxy-3'-methoxyphenyl)-2,4-dioxo-5hexenal or ferulic acid and feruloyl methane were identified as products $[34,35]$. Schneider and co-workers found that oxygen caused an autoxidative transformation of curcumin including several structures which formation was time-dependent, where hemiacetalcyclopentadione, hydroxyketocyclopentadione, and bicyclopentadione were the main products [36-38]. They found that between 20 and $45 \mathrm{~min}$, spiroepoxide and vinylether were also dominant species. In contrast to Masuda's and Wang's results, they proposed a mechanism in which a diketo isomer radical form played an important role in the beginning due to the flexibility of the radical species. This flexible structure allowed the formation of several cyclo and bicyclo species. The most important species of the proposed degradation and autoxidation process can be seen in Scheme 2.

Curcumin's antioxidant properties have been studied in detail. The active site of curcumin has been defined differently:
Tonnesen et al. found that keto-enol formation is responsible for the radical scavenger ability [39] while others claimed that the phenolic group is an active site of scavenging [40, 41]. Jovanovic et al. found that $\mathrm{C}-\mathrm{H}$ cleavage results in active radical species [42]. Due to all these facts, curcumin and alizarin are relevant agents similar to other natural compounds for both the pharmacological and food industry [43]. Both molecules have an extended delocalized electronic system which is a potential partner to stabilize small radicals like hydroxyl, peroxyl, or superoxide radicals, i.e., to form stable radicals with them. Several papers focus strongly on the type of radical formation. These types can be defined as hydrogen atom transfer (HAT), single-electron transfer followed by proton transfer (SET-PT), and sequential proton loss electron transfer (SPLET) [44]. In most computational studies about radical scavengers and their reactions to free radicals, the type of radical formation has been discussed; however, we have found that there is a lack of knowledge about the adduct formation of these well-investigated compounds [45-48]. It is worth mentioning that the degradation of alizarin has been also studied experimentally but only a few mechanistic studies could be found under specific conditions resulting in completely decomposed structures $[49,50]$.

Adducts formed by antioxidants are discussed as follows: interaction and adduct formation in alizarin (AR) and curcumin $(\mathrm{CM})$ with small radicals such as hydroxo radical $\left({ }^{\circ} \mathrm{OH}\right)$, peroxyl radical $\left({ }^{\circ} \mathrm{OOH}\right)$, and superoxide radical $\left(\mathrm{O}_{2}{ }^{-}\right)$- -see the equations below. We studied the rearrangement of the adducts for finding more stable forms, i.e., products in association with the experimental results. On the one hand, we wanted to study the possible rearrangements of alizarin by ROS. On the other hand, we wanted to see whether the proposed mechanisms involving radical forms of curcumin and oxygen molecule are preferred or if another mechanism such as curcumin and small radical interactions can compete with them. 

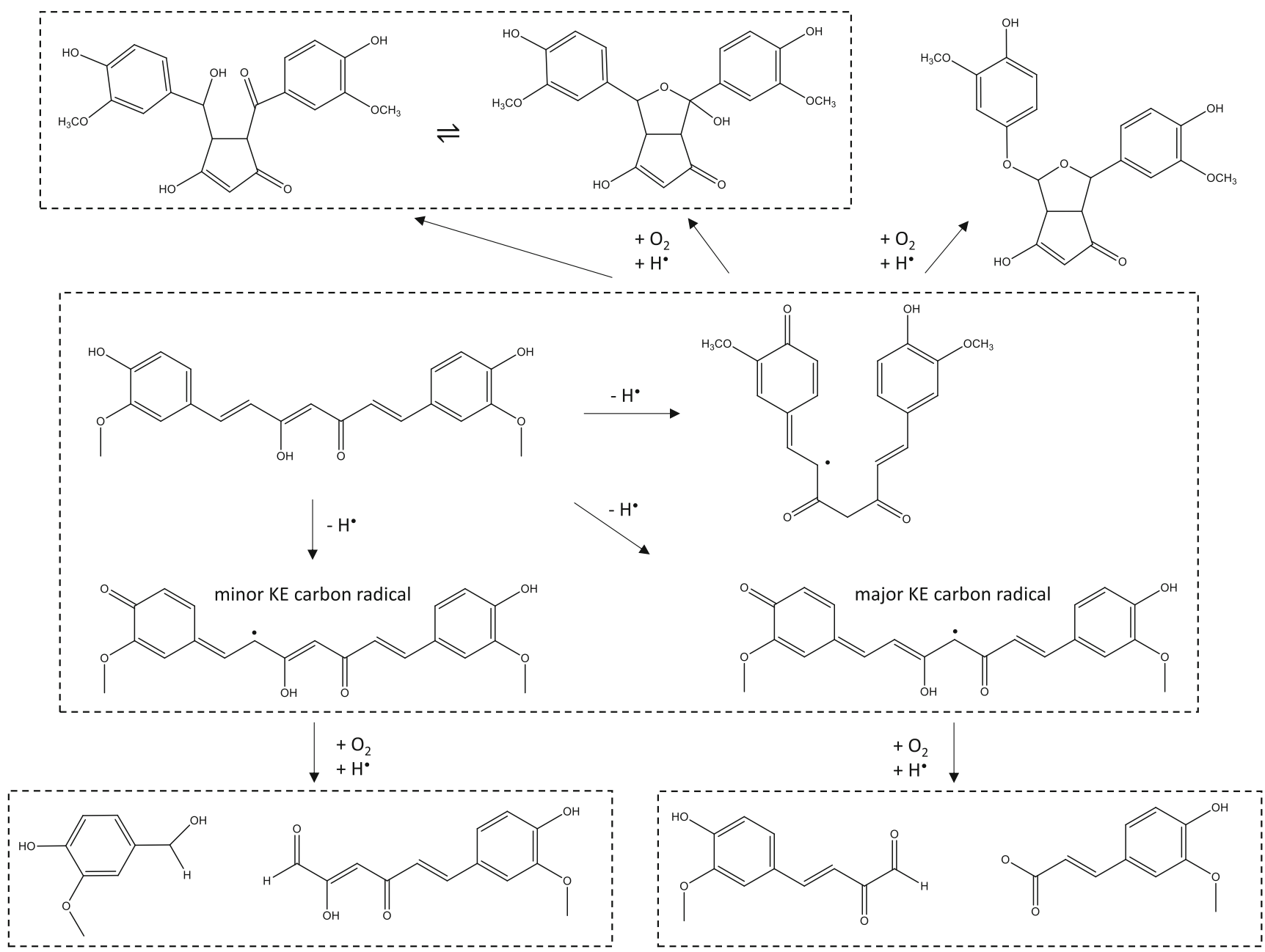

Scheme 2 Proposed autoxidation and degradation processes by experiments

$$
\begin{aligned}
& \mathrm{AR} / \mathrm{CM}+\mathrm{OH}^{\cdot} \rightarrow \mathrm{AR} / \mathrm{CM}^{\bullet}+\mathrm{H}_{2} \mathrm{O} \\
& \mathrm{AR} / \mathrm{CM}+{ }^{\cdot} \mathrm{OH} \rightarrow \mathrm{AR} / \mathrm{CM}-\mathrm{OH}^{\cdot} \\
& \mathrm{AR} / \mathrm{CM}+{ }^{\cdot} \mathrm{OOH} \rightarrow \mathrm{AR} / \mathrm{CM}^{\cdot}+\mathrm{H}_{2} \mathrm{O}_{2} \\
& \mathrm{AR} / \mathrm{CM}+\mathrm{OOH}^{\cdot} \rightarrow \mathrm{AR} / \mathrm{CM}-\mathrm{OOH}^{\cdot} \\
& \mathrm{AR}+\mathrm{O}_{2}^{\cdot-} \rightarrow \mathrm{AR}^{\cdot-}+{ }^{\cdot} \mathrm{OOH} \\
& \mathrm{AR}+\mathrm{O}_{2}{ }^{\cdot-} \rightarrow \mathrm{AR}^{-} \mathrm{O}_{2}{ }^{-} \\
& \mathrm{AR}+\mathrm{O}_{2}{ }^{--} \rightarrow \mathrm{AR}^{\cdot-}+\mathrm{O}_{2}
\end{aligned}
$$

\section{Computational methods}

Density functional theory (DFT) calculations have been carried out using the Gaussian09 software package [51]. Geometry optimizations have been performed with M06-2X functional [52] and TZVP basis sets [53]. Frequency calculations have been done at the theoretical level of geometry optimization. Relative free energies $(\Delta \mathrm{G})$ are reported at $298.15 \mathrm{~K}$ and atmospheric pressure. The solvent (water) effect accounted for the universal SMD (solvation model based on solute electron density) model [54]. All stationary points-minima and transition states (TS) - were proven by frequency analysis where minima had all positive frequencies, and TSs had one imaginary frequency related to the actual movement of the reaction coordinate. All energies are given in $\mathrm{kcal} \mathrm{mol}^{-1}$. In this work, we referred energies to an interacted AR/CM-small radical unit, but we did some comparisons to the separated molecular model to evaluate the effects of our models; see details in the Supplementary Material.

\section{Results and discussion}

\section{Alizarin radical adduct formation}

Alizarin has 14 carbon atoms which are potential partners for radical species, although there are differences among them. Despite the planar structure of AR, the chemical environment around carbon atoms can play an important role since AR can 
form hydrogen bonds with small radicals. Therefore, in all cases, we tried to build starting geometries where the number of H-bonds is maximal.

We found that $\mathrm{H}^{*}$ loss from $-\mathrm{OH}$ on $\mathrm{C} 4$ position $\left(\mathrm{AR}^{\mathrm{C4}{ }^{\circ}}\right)$ is preferred over $-\mathrm{OH}$ of $\mathrm{C} 3\left(\mathrm{AR}^{\mathrm{C} 3 *}\right)$ by $1.4 \mathrm{kcal} \mathrm{mol}^{-1}$ which is in good agreement with previous results [46]. $\mathrm{AR}^{\mathrm{C} 4 \bullet}$ has a planar structure while $\mathrm{AR}^{\mathrm{C} 3 \bullet}$ has a slightly bent. We optimized the radicals derived by hydrogen loss from the aromatic ring and found that those are $24.5-26.7 \mathrm{kcal} \mathrm{mol}^{-1}$ higher in energy than $\mathrm{AR}^{\mathrm{C} 4 \cdot}$. It is not surprising but predicts less relevance for dimerization reactions [55]. We found that in some orientations, there was a barrierless hydrogen transfer to the ${ }^{\circ} \mathrm{OH}$ which formed water and $\mathrm{AR}^{\mathrm{C4} \cdot}$; however, a transition state was found in the case of the coordination to the aromatic plane (adduct formation). The reactant of this elementary step was set as an $\mathrm{AR} \cdots{ }^{\circ} \mathrm{OH}$ reference in which the ${ }^{\circ} \mathrm{OH}$ was $268 \mathrm{pm}$ far from the $\mathrm{C} 4$ atom of $\mathrm{AR}$. It is worth mentioning that by M06, we could find both transition states of water and adduct formations. Coordination to the aromatic ring had a lower activation barrier (see Table S6) but both water and adduct formation were extremely favored thermodynamically. By M062X/TZVP/SMD, $\Delta \mathrm{G}$ was $-22.6 \mathrm{kcal} \mathrm{mol}^{-1}$ for C4-adduct, $-19.6 \mathrm{kcal} \mathrm{mol}^{-1}$ for C6-adduct, and $-32.2 \mathrm{kcal} \mathrm{mol}^{-1}$ for water formation. Note that ${ }^{\circ} \mathrm{OH}$ can interact with AR in different positions, i.e., can get close to AR from many directions, e.g., perpendicular to the aromatic ring; therefore, an adduct formation can be also an option for a radical scavenger. It is worth mentioning that under specific conditions, the complete degradation of alizarin could be detected, and the role of hydroxyl radical was taken into account in the proposed mechanisms $[49,50]$.

In the case of ${ }^{\circ} \mathrm{OOH}$, both transition state and the related reactants could be found by M062X and were shown the kinetic preference of an adduct formation: $\Delta^{\ddagger} \mathrm{G}$ was $19.9 \mathrm{kcal} \mathrm{mol}^{-1}$ for $\mathrm{C} 4$-adduct, $22.6 \mathrm{kcal} \mathrm{mol}^{-1}$ for $\mathrm{C} 6$-adduct, and $26.6 \mathrm{kcal} \mathrm{mol}^{-1}$ for $\mathrm{H}_{2} \mathrm{O}_{2}$ formation. Thermodynamically, the $\mathrm{H}_{2} \mathrm{O}_{2}$ formation was found as a preferred reaction: $\Delta \mathrm{G}$ was $7.9 \mathrm{kcal} \mathrm{mol}^{-1}$ for $\mathrm{C} 4$-adduct (form 1), $9.6 \mathrm{kcal} \mathrm{mol}^{-1}$ for C6-adduct, and $1.4 \mathrm{kcal} \mathrm{mol}^{-1}$ for $\mathrm{H}_{2} \mathrm{O}_{2}$ formation. The adducts, however, were found only as intermediates from which a preroxo bond cleavage could occur. From the $\mathrm{C} 4$-adduct the activation barrier was $27.5 \mathrm{kcal} \mathrm{mol}^{-1}\left(\mathbf{T S}_{1-2}\right)$ and resulted in an extremely stable heptacyclo radical species together with a water molecule $\left(2 ;-44.5 \mathrm{kcal} \mathrm{mol}^{-1}\right)$ after the $\mathrm{C}-\mathrm{C}$ cleavage of the temporarily formed epoxide group (see Scheme 3). It is worth mentioning that the epoxide form could be found by

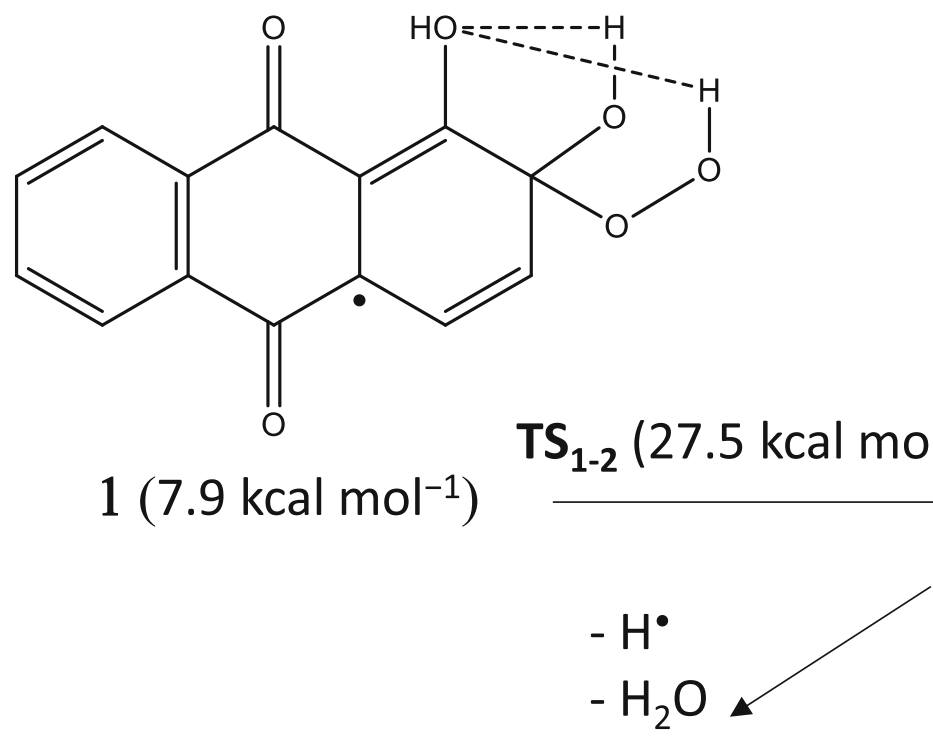<smiles></smiles><smiles>O=C1c2ccccc2C(=O)c2c1ccoc(=O)c2=O</smiles><smiles>CCOC</smiles><smiles>O=c1c2ccoc(O)c(O)c=2c(=O)c2ccccc12</smiles>

Scheme 3 Proposed mechanism for the alizarin-OOH radical systems found by M062X/TZVP/SMD 
both M06 functional and ab initio MP2 methods. The peroxo bond cleavage starting from C6-adduct was significantly higher $\left(39.0 \mathrm{kcal} \mathrm{mol}^{-1}\right)$ resulting in an epoxide form $\left(-24.2 \mathrm{kcal} \mathrm{mol}^{-1}\right)$. The radical form 2 was re-optimized as a singlet state by adding and omitting one hydrogen atom. We found that the formation of the diketo derivative (3) is energetically less favored than the formation of the reduced form (4) of the quinone $\left(\Delta \mathrm{G}=-68.4 \mathrm{kcal} \mathrm{mol}^{-1} \mathrm{vs}\right.$. $75.1 \mathrm{kcal} \mathrm{mol}^{-1}$ ). The optimized structures of the intermediate can be seen in Fig. S1.

We also studied the interaction between alizarin and superoxide radical. No TS was found for the proton transfer from AR to superoxide radical, but the one in which the proton was closer to the $\mathrm{O}_{2}{ }^{--}$had slightly lower energy than the reference one $\left(\Delta \mathrm{G}=-0.8 \mathrm{kcal} \mathrm{mol}^{-1}\right)$. We found that the superoxide "over" the aromatic ring had higher energy due to the lack of hydrogen bond $\left(4.9 \mathrm{kcal} \mathrm{mol}^{-1}\right)$. This form was optimized as a quartet state, and it was found that $\mathrm{O}-\mathrm{O}$ decreased from $130 \mathrm{pm}$ to $119 \mathrm{pm}$ predicting the oxygen molecule formation and had somewhat higher energy than the doublet state of the same orientation $\left(6.3 \mathrm{kcal} \mathrm{mol}^{-1}\right)$. The peroxyl radical coordinated to the $\mathrm{C} 4$ atom of the deprotonated alizarin by $18.2 \mathrm{kcal} \mathrm{mol}^{-1}$ barrier resulted in a stable adduct (5; $2.2 \mathrm{kcal} \mathrm{mol}^{-1}$ ) that was lower than the coordination of the $\mathrm{O}_{2}{ }^{--}$to the AR $\left(24.7 \mathrm{kcal} \mathrm{mol}^{-1}\right)$. From 5 which is the deprotonated form of $\mathrm{C} 4$ adduct, the peroxo bond cleavage went through a lower barrier $\left(\mathbf{T S}_{5-6}\right)$ than in the case of $\mathbf{T S}_{\mathbf{1 - 2}}$ by $4.7 \mathrm{kcal} \mathrm{mol}^{-1}$ resulting in $6\left(10.6 \mathrm{kcal} \mathrm{mol}^{-1}\right)$ in which the negative charge was mostly located on the remaining $-\mathrm{O}^{-}$ group. The $\mathrm{C} 4$ atom of $\mathbf{6}$ had also a-OH group, from which a proton transfer could occur almost spontaneously $\left(\mathbf{T S}_{\mathbf{6}-7}\right)$, and resulted in another stable heptacyclo derivative (7). Note that 6 had lower electronic energy than $\mathbf{T S}_{6-7}$ by $1.6 \mathrm{kcal} \mathrm{mol}^{-1}$. We optimized 7 as a neutral species $(\mathbf{8})$ and a reduced form (9) and was found that both the oxo heptacyclo derivative was more stable than 3 by $14.5 \mathrm{kcal} \mathrm{mol}^{-1}$ and the reduced form was also more stable than 4 by $24.1 \mathrm{kcal} \mathrm{mol}^{-1}$. The oxidation products $\mathbf{3}$ and $\mathbf{8}$ are ether derivatives of tropolones which widely occur in nature [56] and can be synthesized from polyhydroxy benzene derivatives [57]. In the case of crocipodin and thujaplicin synthesis, the oxidizing agent was hydrogen peroxide. The structures of the stationary points can be seen in Scheme 4. Note that the formation was the same by MP2 and M06 methods skipping an epoxide species.

\section{Curcumin radical formation}

Curcumin has two tautomer forms: a diketo (DK) and a ketoenol (KE) isomer (see Scheme 2); the latter one is more stable by $2.4 \mathrm{kcal} \mathrm{mol}^{-1}$. It is in good agreement with the literature since enol form can be the dominant (up to 95\%) isomer depending on the solvent $[58,59]$. Our calculated energy difference predicts only $1-2 \%$ of keto form due to the Boltzmann distribution.

Since DK has an $\mathrm{sp}^{3}$ carbon in the central position, only 18 carbon atoms are a potential partner for adduct formation, while in the case of $\mathrm{KE}$ the central $\mathrm{C} 1$ carbon atom can play an important role. We found that hydrogen atom loss from the $-\mathrm{OH}$ group of the $\mathrm{KE}$ isomer at the $\mathrm{C} 8$ position $\left(\mathrm{KE}^{\mathrm{C} 8} ; \mathbf{1 0}\right.$ in Scheme 5) was slightly more stable than the other side $\left(\mathrm{KE}^{\mathrm{C} 17 \cdot} ; 0.5 \mathrm{kcal} \mathrm{mol}^{-1}\right)$. The radical proposed by Jovanovic $\left(\mathrm{DK}^{\mathrm{Cl}}{ }^{\circ}\right)$ [42] was, however, unfavored $\left(12.0 \mathrm{kcal} \mathrm{mol}^{-1}\right)$, while other radicals formed by $\mathrm{H}$-loss from $\mathrm{C} 3, \mathrm{C} 4, \mathrm{C} 12$, and $\mathrm{C} 13$ atoms had very high relative energies (over $25 \mathrm{kcal} \mathrm{mol}^{-1}$ ). The interaction of these radicals with oxygen molecule was also studied which were previously suggested in the literature [34-38] as well as the adduct formation by peroxyl and superoxide radicals; see later.

Gordon, Schneider et al. proposed that $\mathrm{DK}^{\mathrm{C} 8 \cdot}$ which is a para-quinone methide derivative can play an important role in the autoxidation of curcumin [35]. We studied the proposed mechanism, and firstly we did calculations to find the most stable forms, i.e., the most preferred pathway for the preautoxidation process (Scheme 5), in which there is no oxygen molecule. We found that the bent conformer of $\mathrm{DK}^{\mathrm{C} 8 \bullet}(\mathbf{1 1})$ proposed by Schneider et al. was slightly more stable than the non-bent conformer ( 2.3 vs. $\left.3.1 \mathrm{kcal} \mathrm{mol}^{-1}\right)$ due to the stacking interaction between the aromatic rings. Among the optimized forms $\mathbf{1 1}$ and $\mathbf{1 3}$, the non-radical form of $\mathbf{1 5}$ was published in their work. We found, however; that the diketo form $\mathbf{1 2}$ was slightly but the DK isomer $\mathbf{1 4}$ was strongly preferred in contrast to the KE radicals $\mathbf{1 1}$ and $\mathbf{1 3}$.

Furthermore, we found other very stable cyclointermediates (16 and 17), which can be formed by an $\mathrm{H}$ transfer from the pentagonal cyclo-ring to the keto group of the quinonoid ring because the direct formation of $\mathbf{1 6}$ from a high-energy species $\left(\mathrm{DK}^{\mathrm{C} 3 \cdot} ; 27.2 \mathrm{kcal} \mathrm{mol}^{-1}\right)$ is less favored than the formation of $\mathbf{1 2}\left(\mathbf{T S}_{\mathbf{1 1 - 1 2}} ; 20.6 \mathrm{kcal} \mathrm{mol}^{-1}\right)$. The main reason for the stabilization of $\mathbf{1 6}$ and $\mathbf{1 7}$ could be based on the huge structural difference. While $\mathbf{1 2}$ and $\mathbf{1 3}$ had an unfavored bent quinone after the cyclization step, then in $\mathbf{1 6}$ and $\mathbf{1 7}$, the aromatic rings were almost perpendicular to each other resulting in no strain for the $\mathrm{C}=\mathrm{C}$ bond (see Fig. S2).

\section{Autoxidation of curcumin}

The autoxidation process was studied starting from 12, 13, 16, and $\mathbf{1 7}$, and it was found that DK isomers were preferred to form adducts by an oxygen molecule (see Scheme 6). It can be seen that the preference of $\mathbf{1 6}$ over $\mathbf{1 2}$ is balanced during the peroxo bridge formation; $\mathbf{1 8}$ was much more stable than $\mathbf{2 0}$, but the TSs and the intermediates $\mathbf{1 9}$ and $\mathbf{2 1}$ had almost the same energies.

Since experimentally the KE isomers were identified, we represent the further rearrangement of the KE radicals; 


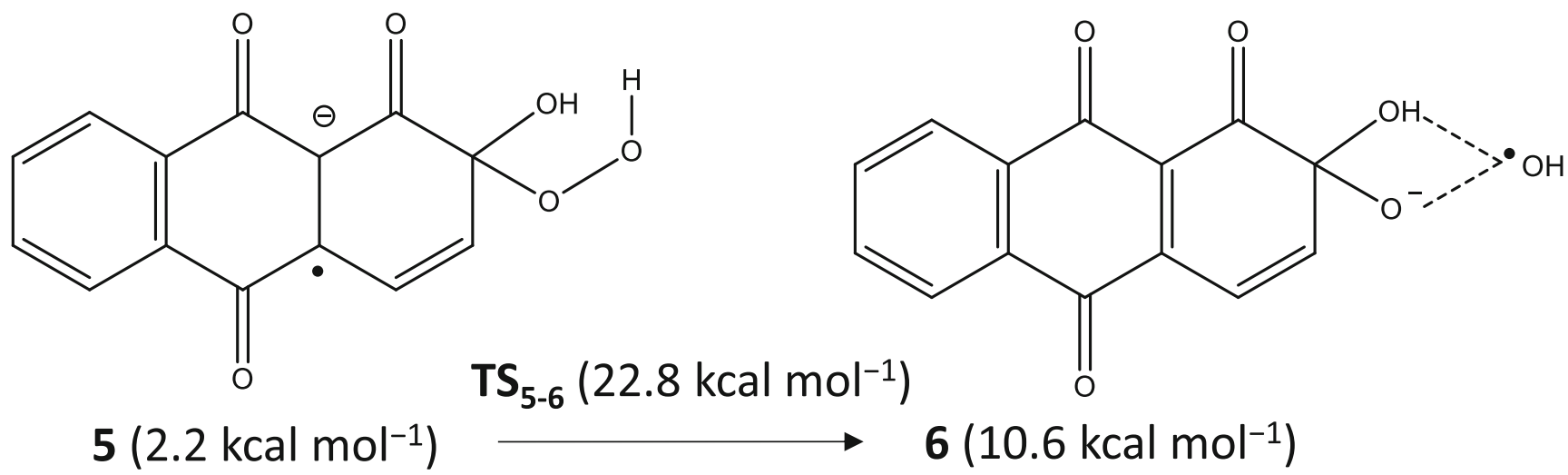

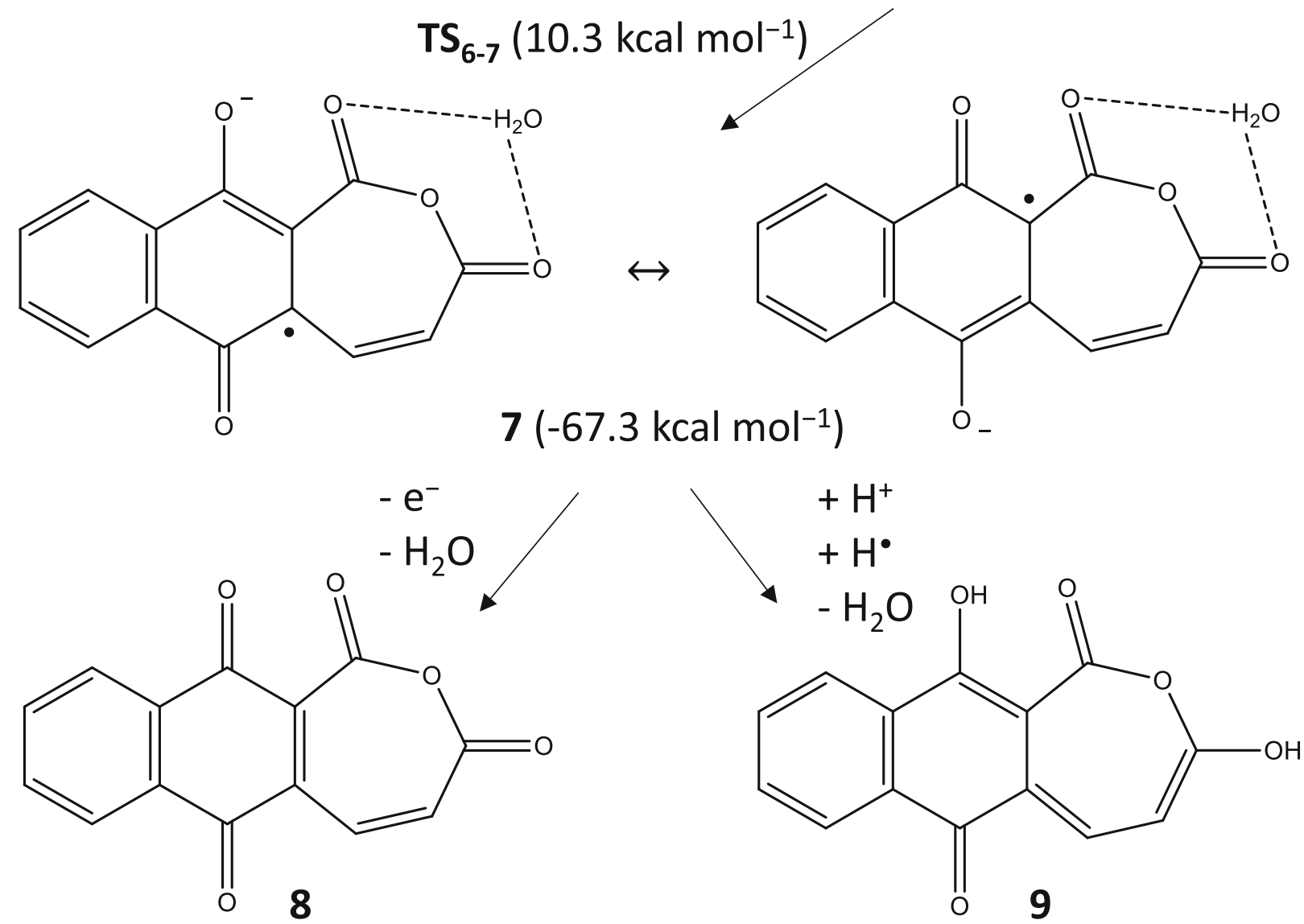

Scheme 4 Proposed mechanism for the alizarin- $\mathrm{OO}^{-}$radical systems found by M062X/TZVP

however, it is worth mentioning that in general, DK radicals are preferred by $2-4 \mathrm{kcal} \mathrm{mol}^{-1}$ (M06 results), but the final non-radical products are more stable as KE isomer. For example, from 22 (the KE isomer of 21), the transition state of the epoxide formation had higher energy $\mathbf{( T S}_{\mathbf{2 2} 2 \mathbf{2 3}}$; $\left.24.9 \mathrm{kcal} \mathrm{mol}^{-1}\right)$ than for DK isomer $\left(22.6 \mathrm{kcal} \mathrm{mol}^{-1}\right)$; however, the DK analog of $\mathbf{2 3}$ was an exception which had slightly higher energy $\left(-11.2 \mathrm{kcal} \mathrm{mol}^{-1}\right)$ than the KE radical species 23. A hydrogen transfer from the ring of $\mathbf{2 3}$ to the $-\mathrm{O}^{\circ}$ group resulted in a very stable form (24) from which epoxide opening could occur in two ways.
One of them could be a multistep process including two hydrogen transfers and causing the epoxide unit opening and the quinone $\rightarrow$ phenolic ring transition $(\mathbf{2 4} \rightarrow \mathbf{2 5})$. From $\mathbf{2 5}$, a bicyclopentadione radical (26) was formed by the coordination of the $-\mathrm{O}^{\bullet}$ group through a not high barrier (see Scheme 7). By uptaking of a hydrogen atom, the hydroxyketocyclopentadione product derived from $\mathbf{2 5}$ was slightly more stable than the hemiacetalcyclopentadione derived from $26\left(\Delta \mathrm{G}=0.6 \mathrm{kcal} \mathrm{mol}^{-1}\right)$ predicting the equilibrium as was discussed by Gordon, Schneider et al. [37]. They proposed that both products could be formed from the 
<smiles>COC1=CC(/C=C/C(O)=C/C(=O)/C=C/c2ccc(O)c(OC)c2)=CC(=O)C1=O</smiles>

$10\left(0.0 \mathrm{kcal} \mathrm{mol}^{-1}\right)$<smiles>COC1=CC(=CC=CC(=O)CC(=O)C=Cc2ccc(O)c(OC)c2)C=CC1=O</smiles>

$11\left(2.3 \mathrm{kcal} \mathrm{mol}^{-1}\right)$

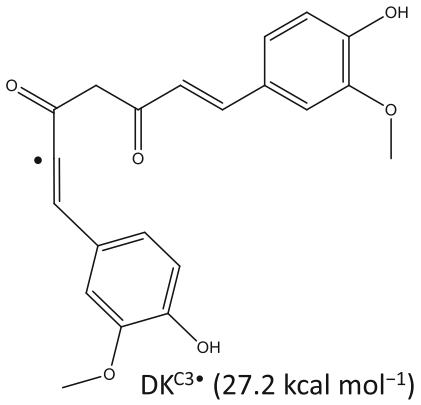

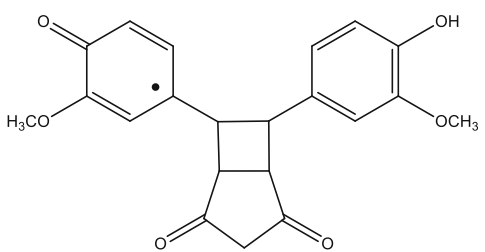

$14\left(23.3 \mathrm{kcal} \mathrm{mol}^{-1}\right)$

$\mathrm{TS}_{9-11}\left(35.1 \mathrm{kcal} \mathrm{mol}^{-1}\right)$

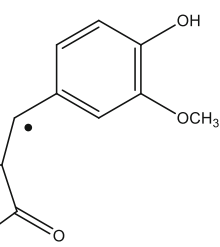

$12\left(10.3 \mathrm{kcal} \mathrm{mol}^{-1}\right)$

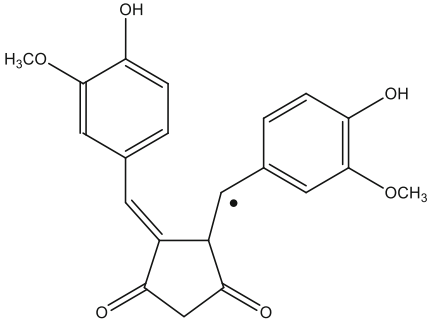

$16\left(-5.7 \mathrm{kcal} \mathrm{mol}^{-1}\right)$

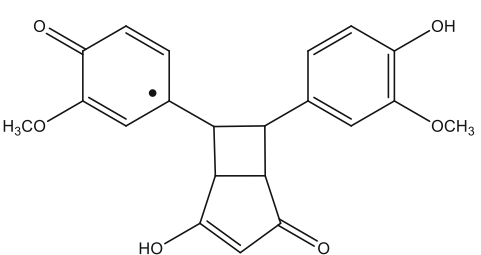

$15\left(35.1 \mathrm{kcal} \mathrm{mol}^{-1}\right)$

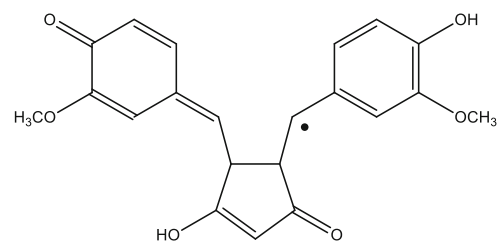

$13\left(11.6 \mathrm{kcal} \mathrm{mol}^{-1}\right)$

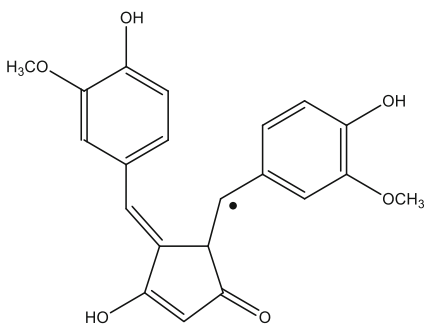

$17\left(-6.2 \mathrm{kcal} \mathrm{mol}^{-1}\right)$

Scheme 5 Relevant radical forms of the pre-autoxidation process. Energies are calculated by M062X/TZVP/SMD<smiles>COC1=CC(=CC2C(=O)CC(=O)C2C(O[O-])c2ccc(O)c(OC)c2)C=CC1=O</smiles>

$20\left(12.1 \mathrm{kcal} \mathrm{mol}^{-1}\right)$<smiles>[CH2]OC(c1ccc(O)c(OC)c1)C1C(=O)CC(=O)/C1=C/c1ccc(O)c(OC)c1</smiles>

$18\left(0.0 \mathrm{kcal} \mathrm{mol}^{-1}\right)$

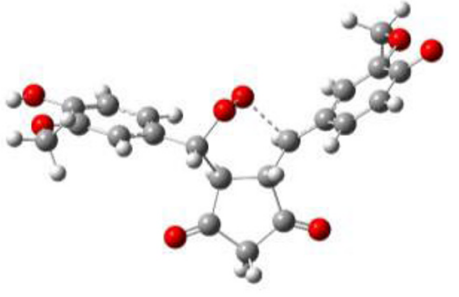

$\mathrm{TS}_{20-21}\left(21.9 \mathrm{kcal} \mathrm{mol}^{-1}\right)$<smiles>COc1cc(C2OOC(c3ccc(O)c(O)c3)C3C(=O)CC(=O)C23)ccc1O</smiles>

$21\left(-5.1 \mathrm{kcal} \mathrm{mol}^{-1}\right)$

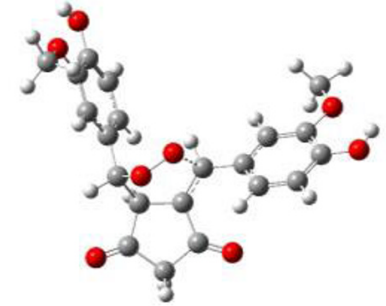

$\mathrm{TS}_{18-19}\left(20.4 \mathrm{kcal} \mathrm{mol}^{-1}\right)$<smiles>COc1cc(C2OOC(c3ccc(O)c(OC)c3)[C@H]3C(=O)CC(=O)C23)ccc1O</smiles>

$19\left(-4.8 \mathrm{kcal} \mathrm{mol}^{-1}\right)$

Scheme 6 The first step of the autoxidation process. Energies are calculated by M062X/TZVP/SMD 
proposed but non-isolated endoperoxide intermediate (derived from 21 and 22 by uptaking a hydrogen atom). We found that both endoperoxide isomers had extremely high energy referred to hydroxyketocyclopentadione (KE isomer was at $72.2 \mathrm{kcal} \mathrm{mol}^{-1}$; DK isomer was at $67.4 \mathrm{kcal} \mathrm{mol}^{-1}$ ). Schneider et al. declared that the opening of the endoperoxide moiety could occur by a Kornblum-DeLaMare rearrangement [60]. We found that the deprotonation of $\mathrm{C}-\mathrm{H}$ of the endoperoxide's pentadione ring by an $\mathrm{OH}^{-}$was both kinetically and thermodynamically preferred $\left(\Delta^{\ddagger} \mathrm{G}=4.1 \mathrm{kcal} \mathrm{mol}^{-1} ; \Delta \mathrm{G}_{\mathrm{r}}=\right.$ $-10.3 \mathrm{kcal} \mathrm{mol}^{-1}$ ), but not surprisingly, the deprotonated species had higher energy than the one which was deprotonated on the $-\mathrm{OH}$ of the endoperoxide's DK isomer $(\Delta \mathrm{G}=$ $12.9 \mathrm{kcal} \mathrm{mol}^{-1}$ ). The main problem was, however; that calculations showed an unfavored formation for the DK isomer of the endoperoxide intermediate by the reaction of $\mathbf{2 1}+$ water molecule $\left(\Delta^{\ddagger} \mathrm{G}=37.9 \mathrm{kcal} \mathrm{mol}^{-1} ; \Delta \mathrm{G}_{\mathrm{r}}=33.3 \mathrm{kcal} \mathrm{mol}^{-1}\right)$. Therefore, we concluded that the formation of hydroxyketocyclopentadione and hemiacetalcyclopentadione could be through radical species $(\mathbf{2 3} \rightarrow \mathbf{2 6}$; see Scheme 7). Note that the activation barrier for the elementary step of the epoxide formation from DK isomer 21 was $27.7 \mathrm{kcal} \mathrm{mol}^{-1}$ (TS from 21 had the energy of $22.6 \mathrm{kcal} \mathrm{mol}^{-1}$ ) but from the less stable KE isomer 22, the elementary step had $23.8 \mathrm{kcal} \mathrm{mol}^{-1}$ barrier (see Scheme 7).

The non-radical spiroepoxide derived from $\mathbf{2 3} / \mathbf{2 4}$ $\left(39.4 \mathrm{kcal} \mathrm{mol}^{-1}\right)$ as well as the isolated products of the other branch of autoxidation; the vinylethercyclopentadione product derived from $\mathbf{2 7 / 2 8}\left(14.3 \mathrm{kcal} \mathrm{mol}^{-1}\right)$ and the bicyclopentadione derived from $29\left(8.7 \mathrm{kcal} \mathrm{mol}^{-1}\right)$ had high energy referred to hydroxyketocyclopentadione product. Experimentally, however, the bicyclopentadione was found as the major product. This contradiction can be simply explained by that from the epoxide radical 24 , the CC cleavage of the epoxide unit could occur through a low barrier $\mathbf{T S}_{\mathbf{2 4}}$
${ }_{27}$ ) resulting in the very stable vinylethercyclopentadione radical (27) while the $\mathbf{2 4} \rightarrow \mathbf{2 5} \rightarrow \mathbf{2 6}$ pathway had a more complicated rearrangement including outer sphere hydrogen transfers which could be kinetically controlled. However, from 27, a much less favored radical species (28) was found after a hydrogen atom transfer from the $-\mathrm{OH}$ group to the oxygen atom of the quinonic ring which seems to be much easier than the $\mathrm{H}$ transfers predicted for the $\mathbf{2 4} \boldsymbol{\mathbf { 2 5 }}$ transition including $\mathrm{H}$ transfers from and to the carbon atoms of the cyclopentadione ring. The resting $-\mathrm{O}^{\circ}$ group of $\mathbf{2 8}$ could also coordinate to $\mathrm{sp}^{2}$ carbon atom forming the bicyclopentadione radical (29). We found that bicyclopentadione had cis configuration to the cyclopentadione ring as was found experimentally; the trans isomer had $20.7 \mathrm{kcal} \mathrm{mol}^{-1}$ higher energy than the $c i s$ isomer. Despite that the orientation of the $-\mathrm{OH}$ group was good relative to the cyclopentadione ring in form $\mathbf{2 7}$, the formation of the trans radical species was also unfavored. Spiroepoxide and vinylethercyclopentadione were also detected experimentally which can be due to the unfavored longterm rearrangements of outer-sphere hydrogen transfers in the case of $\mathbf{2 4} \rightarrow \mathbf{2 5}$ and $\mathbf{2 7} \rightarrow \mathbf{2 8}$.

Gordon et al. proposed that the spiroepoxide intermediate had an oxygen exchange found by ${ }^{18} \mathrm{O}$ NMR. Due to the very stable $\mathbf{2 6}$ form, we suggest that the oxygen exchange occurs after the epoxide ring opens through a low barrier; therefore, $\mathbf{2 6}$ is a kind of thermodynamic cage during the process.

\section{Degradation of curcumin by small radicals}

We found that the Jovanovic-type radical $\left(\mathrm{DK}^{\mathrm{Cl} \bullet}\right)$ formed an adduct with oxygen molecule which had higher energy $\left(15.1 \mathrm{kcal} \mathrm{mol}^{-1}\right)$ than the cyclopentadione DK forms $\mathbf{1 8}$ and 20 in Scheme 6. The peroxo bond cleavage starting from it had very high activation energy $\left(51.9 \mathrm{kcal} \mathrm{mol}^{-1}\right)$ due to the concerted step of the $\mathrm{C}-\mathrm{C}$ and $\mathrm{O}-\mathrm{O}$ cleavages resulting in the

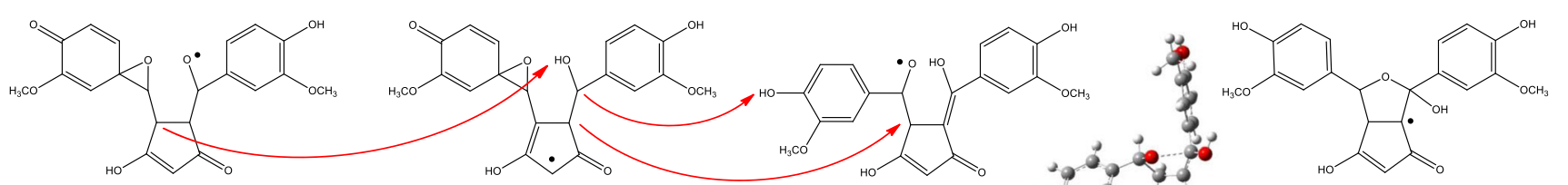
$23\left(-11.6 \mathrm{kcal} \mathrm{mol}^{-1}\right)$ $24\left(-28.8 \mathrm{kcal} \mathrm{mol}^{-1}\right)$

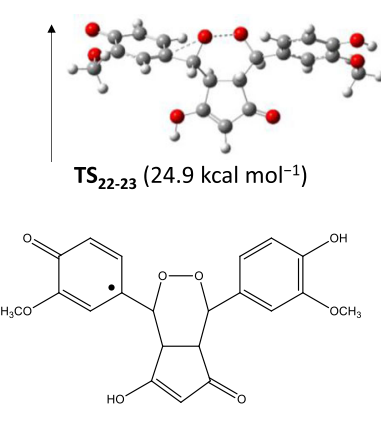

22 (1.1 kcal mol-1)

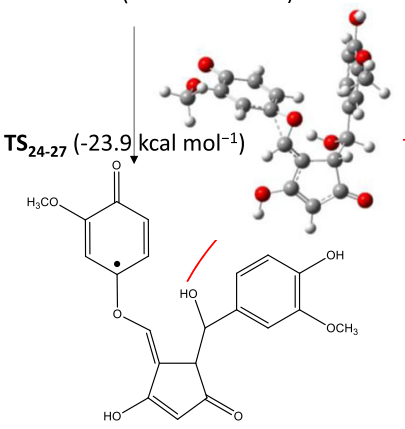

27 (-62.2 kcal mol-1$)$ $25\left(-48.3 \mathrm{kcal} \mathrm{mol}^{-1}\right)$

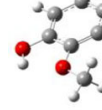

$\mathrm{TS}_{25-26}\left(-34.2 \mathrm{kcal} \mathrm{mol}^{-1}\right)$

Scheme 7 Scheme of the autoxidation process of the KE isomer involving the epoxide intermediate. Energies are calculated by M062X/TZVP/SMD 
very stable product of ferulic acetate and an aldehyde radical derivative of feruloyl methane $\left(-49.0 \mathrm{kcal} \mathrm{mol}^{-1}\right)$.

The $\mathrm{O}_{2}$ adducts of minor and major KE carbon radicals defined by Matsuda et al. had much higher energies (29.6 and $31.7 \mathrm{kcal} \mathrm{mol}^{-1}$ ) than other previously mentioned $\mathrm{O}_{2}$ adduct species. We studied the cyclization from these species and found that the activation barriers were very high (50.2 and $39.3 \mathrm{kcal} \mathrm{mol}^{-1}$ ) which showed a kinetic preference for the major product between the two unfavored pathways. The OOcyclic products having four-membered rings were also unstable (21.3 and $24.1 \mathrm{kcal} \mathrm{mol}^{-1}$ ). Masuda et al. concluded that these species formed in a non-polar medium; therefore, we made a single point in vacuo calculations for $\mathbf{2 0}, \mathbf{2 1}$, and the minima forms proposed by Masuda. It was found that $\mathbf{2 0}$ had higher energy by $4.5 \mathrm{kcal} \mathrm{mol}^{-1}$, while Masuda's species had somewhat lower energies $\left(2-4 \mathrm{kcal} \mathrm{mol}^{-1}\right)$ referred to 21 , but 20 remained more stable than Matsuda's species in vacuo.

Due to the high energies of the $\mathrm{O}_{2}$ adducts in terms of degradation, we also studied the effect of peroxyl and superoxide radicals and found two pathways that had much lower activation barriers than the $\mathrm{O}_{2}$ adducts formed by Jovanovicand Matsuda-type radicals. One of them, starting from the $\mathrm{C} 4$ adduct of $\mathrm{KE}^{-\mathrm{OOH}^{*}}(\mathbf{3 0})$ which is the most stable peroxyl<smiles>[CH2][C@@H](O)OC(C/C(O)=C/C(=O)/C=C/c1ccc(O)c(OC)c1)c1ccc(O)c(OC)c1</smiles>

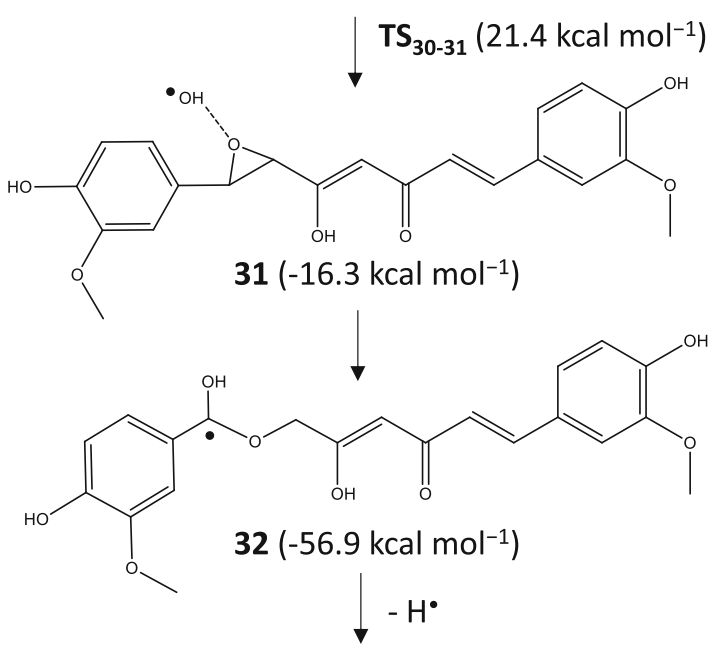<smiles>COc1cc(/C=C/C(=O)/C=C(\O)C(=O)O)ccc1O</smiles>

Scheme 8 Proposed mechanism starting from the $\mathrm{C} 4$ adduct of the curcumin + peroxyl radical system resulting in vanillin and 6-(4'hydroxy-3'-methoxyphenyl)-2,4-dioxo-5-hexenal adduct formed an epoxide species (31) after the peroxo bond cleavage $\left(\mathbf{T S}_{\mathbf{3 0 - 3 1}}\right)$. The generated free ${ }^{\circ} \mathrm{OH}$ could coordinate to the $\mathrm{C} 4$ atom resulting in a very stable radical form (32) which gave the minor vanillin and 6-(4'-hydroxy-3'methoxyphenyl)-2,4-dioxo-5-hexenal products (33) after a hydrogen atom loss in a barrierless step (see Scheme 8).

The other favored degradation pathway was starting from the $\mathrm{C} 1$ adduct of $\mathrm{KE}-\mathrm{OOH}^{*}(\mathbf{3 4})$ which had $1.9 \mathrm{kcal} \mathrm{mol}^{-1}$ higher energy than the $\mathrm{C} 4$ adduct. From this, a peroxo bond cleavage occurred $\left(\mathbf{T S}_{\mathbf{3 4 - 3 5}}\right)$ which had a lower barrier by $1.8 \mathrm{kcal} \mathrm{mol}^{-1}$ than that of $\mathbf{T S}_{\mathbf{3 0 - 3 1}}$. The free ${ }^{\circ} \mathrm{OH}$ in $\mathbf{3 5}$ could coordinate to the $\mathrm{C} 2$ atom $\left(\mathbf{T S}_{\mathbf{3 5 - 3 6}}\right)$ resulting in a very stable radical species (36) from which after a hydrogen loss the major degradation product ferulic acid and the aldehyde derivative of feruloylmethane (37) formed (see Scheme 9).

As the relative energy of the degradation products showed, ferulic acid + feruloyl methane derivative was more stable by $5.3 \mathrm{kcal} \mathrm{mol}^{-1}$ than $o$-vanillin + trans-6-(4'-hydroxy-3'methoxyphenyl)-2,4-dioxo-5-hexenal which means a thermodynamic preference of the major degradation products identified experimentally $[34,35]$. The minor degradation products had relative energy of $22.9 \mathrm{kcal} \mathrm{mol}^{-1}$ while the major product had $17.6 \mathrm{kcal} \mathrm{mol}^{-1}$ referred to as the most stable product of the autoxidation process. These energy values were between<smiles>COc1cc(/C=C/C(=O)C(OO)C(O)/C=C/c2ccc(O)c(OC)c2)ccc1O</smiles>

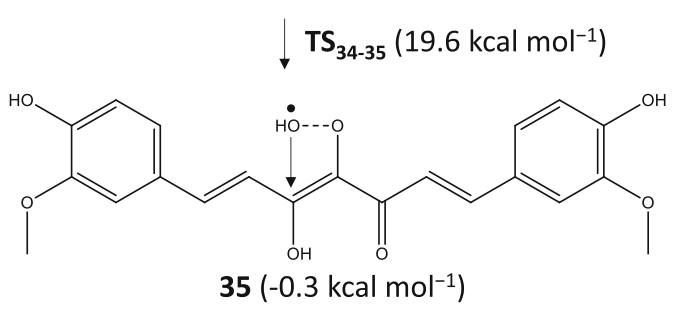

$\mathrm{TS}_{35-36}\left(5.6 \mathrm{kcal} \mathrm{mol}^{-1}\right)$<smiles>COc1cc(/C=C/C(=O)C([O])C(O)(O)/C=C/c2ccc(O)c(OC)c2)ccc1O</smiles>

$36\left(-35.0 \mathrm{kcal} \mathrm{mol}^{-1}\right)$<smiles>COc1cc(/C=C/C(=O)C=O)ccc1O</smiles>

Scheme 9 Proposed mechanism starting from the $\mathrm{C} 1$ adduct of the curcumin + peroxyl radical system resulting in ferulic acid and a feruloyl methane derivative 
the energies of spiroepoxide and vinylethercyclopentadione intermediates.

In the case of superoxide, the $\mathrm{C} 1$ adduct was more stable than the $\mathrm{C} 4$ adduct by $3.3 \mathrm{kcal} \mathrm{mol}^{-1}$ while the peroxo bond cleavage was also preferred for the $\mathrm{C} 1$ adduct by $4.9 \mathrm{kcal} \mathrm{mol}^{-1}$. All these results predict that peroxyl and superoxide radicals are responsible for the degradation instead of oxygen molecule.

\section{Conclusion}

In this work, we studied the antioxidant ability of two wellknown natural compounds, alizarin and curcumin. Reactions with small harmful radicals such as hydroxyl, peroxyl, and superoxide radicals were investigated in detail by solvent models. We made a detailed mechanistic study, and found that hydroxyl radical can coordinate to the alizarin ring resulting in very stable adducts due to the possible orientation of the radical indicating further decomposition process. Peroxyl radical did not form stable adducts, but kinetically more preferred than hydrogen peroxide formation despite the latter one is thermodynamically favored. From the peroxyl adducts after the peroxo bond cleavage, different oxo heptacyclo species could form (see Scheme 10). These oxidation species are ether derivatives of the naturally occurring tropolones which have previously never been proposed. We found that all species are extremely favored thermodynamically; however, the formation of the more stable 1,3-dioxo heptacyclo species was kinetically preferred by superoxide radical. In biological systems, these products can be formed but further decompositions can be also proposed.

The autoxidation process of curcumin in which oxygen interacts with the radical forms of curcumin was studied in detail. It was found that the diketo isomer is responsible for the first steps due to the flexibility it compared to the rigid ketoenol isomer, which is in good agreement with the experimental results. We studied the possible pathways of the autoxidation through cyclic radical forms and found that the key intermediate is the epoxide form (see Scheme 10) from which all cyclopentadione could be formed in contrast to the experimentally proposed mechanism where only the bicyclopentadione pathway was assumed from the epoxide intermediate. However, the formation of hydroxyketocyclopentadione and hemiacetalcyclopentadione products was proposed before by ionic rearrangement; we showed that the mechanism including only radical species was much more favored and could explain some important questions. On the one hand, experimentally bicyclopentadione was found as a major product but our calculations showed that it had significantly higher energy compared to hydroxyketocyclopentadione and hemiacetalcyclopentadione which were in equilibrium experimentally and also by our calculations. This contradiction could be explained by the low activation barrier of the CC-cleavage of the epoxide unit resulted in the very stable vinylethercyclopentadione radical form (see Scheme 10). On the other hand, we concluded that the experimental appearance of the very unfavored

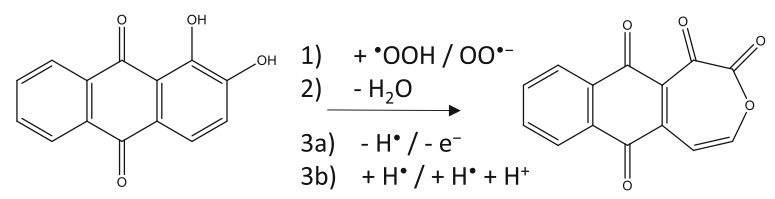<smiles></smiles><smiles></smiles><smiles></smiles><smiles>CC1=CC2(C=CC1=O)OC2C1=C(O)C(=O)C=C1C(O)c1ccc(O)c(O)c1</smiles>

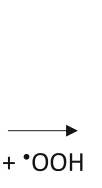<smiles>C/C=C/c1ccc(O)c(OC)c1</smiles><smiles>C/C=C/C(=O)C(O)C(O)/C=C/C</smiles><smiles>COc1cc(I)ccc1O</smiles><smiles>COc1cc(/C=C/C(=O)/C=C(\O)C2C(O)C2c2ccc(O)c(OC)c2)ccc1O</smiles><smiles>COc1cc(/C=C/C(=O)/C=C(\O)COC(O)c2ccc(O)c(OC)c2)ccc1O</smiles><smiles>O=c1c2occcc(O)c=2c(=O)c2ccccc12</smiles><smiles>O=C1OC(=O)C2=C(O)C1=CC=C(O)OC2=O</smiles>

Autoxidation products Hydroxyketocyclopentadione Hemiacetalcyclopentadione Bicyclopentadione

Ferulic acid Feruloyl methane

Degradation products o-Vanillin

6-(4'-hydroxy-3'methoxyphenyl)-2,4-dioxo-5hexenal

Scheme 10 Summary of the most important species found by DFT calculations 
spiroepoxide and vinylethercyclopentadione intermediates was based on the long-term rearrangements of hydrogen atoms, i.e., outer sphere hydrogen transfers.

The minor and major degradation products of curcumin could be found by some rearrangements starting from adducts formed by peroxyl and superoxide radicals. The activation barriers were much lower than those derived from the reaction between the open-chain radical form of curcumin and the oxygen molecule, which was experimentally proposed.

Comparing alizarin to curcumin, it can be concluded that the rigid alizarin can also transform into oxidized species by peroxyl or superoxide radicals. Activation barriers of the superoxidealizarin pathways are similar to the barriers of curcumin's autoxidation and degradation processes that propose a possible oxidation reaction in the case of alizarin as well.

Supplementary Information The online version contains supplementary material available at https://doi.org/10.1007/s00894-021-04778-1.

Acknowledgments This work was partially supported by the European Union and the European Social Fund through project Supercomputer, the National Virtual Lab, grant no.: TÁMOP-4.2.2.C-11/1/KONV-20120010. The authors would like to thank Prof. Daniel W. Ingersoll for his constructive criticism and proofreading of the manuscript.

Availability of data and material Not applicable.

Code availability Not applicable.

Author contribution Malek Sadatsharifi: Conceptualization, lead validation, formal analysis, supporting investigation, resources, writing - original draft, writing - review and editing, visualization, project administration.

Mihály Purgel: Conceptualization, supporting methodology, software validation, formal analysis, lead investigation, resources, data curation, writing - original draft, writing - review and editing, visualization, supervision, project administration, funding acquisition

Funding Open access funding provided by University of Debrecen. This work was partially supported by the European Union and the European Social Fund through project Supercomputer, the National Virtual Lab, grant no.: TÁMOP-4.2.2.C-11/1/KONV-2012-0010.

\section{Declarations}

Ethics approval Not applicable.

Consent to participate Not applicable.

Consent for publication Not applicable.

Conflict of interest The authors declare no competing interests.

Open Access This article is licensed under a Creative Commons Attribution 4.0 International License, which permits use, sharing, adaptation, distribution and reproduction in any medium or format, as long as you give appropriate credit to the original author(s) and the source, provide a link to the Creative Commons licence, and indicate if changes were made. The images or other third party material in this article are included in the article's Creative Commons licence, unless indicated otherwise in a credit line to the material. If material is not included in the article's Creative Commons licence and your intended use is not permitted by statutory regulation or exceeds the permitted use, you will need to obtain permission directly from the copyright holder. To view a copy of this licence, visit http://creativecommons.org/licenses/by/4.0/.

\section{References}

1. Murphy MP, Holmgren A, Larsson NG, Halliwell B, Chang CJ, Kalyanaraman B, Rhee SG, Thornalley PJ, Partridge L, Gems D, Nyström T, Belousov V, Schumacker PT, Winterbourn CC (2011) Unraveling the biological roles of reactive oxygen species. Cell Metab 12:361-366. https://doi.org/10.1016/j.cmet.2011.03.010

2. Kalyanaraman B, Cheng G, Hardy M, Ouari O, Bennett B, Zielonka J (2018) Teaching the basics of reactive oxygen species and their relevance to cancer biology: mitochondrial reactive oxygen species detection, redox signaling, and targeted therapies. Redox Biol 15:347-362. https://doi.org/10.1016/j.redox.2017.12. 012

3. Nilsson R, Liu NA (2020) Nuclear DNA damages generated by reactive oxygen molecules (ROS) under oxidative stress and their relevance to human cancers, including ionizing radiation-induced neoplasia part I: physical, chemical and molecular biology aspects. Radiat Med Prot 1:140-152. https://doi.org/10.1016/j.radmp.2020. 09.002

4. Lam PL, Wong RSM, Lam KH, Hung LK, Wong MM, Yung LH, Ho YW, Wong WY, Hau DKP, Gambari R, Chui C-H (2020) The role of reactive oxygen species in the biological activity of antimicrobial agents: an updated mini review. Chem Biol Interact 320: 109023-109035. https://doi.org/10.1016/j.cbi.2020.109023

5. Rendra E, Riabov V, Mossel DM, Sevastyanova T, Harmsen MC, Kzhyshkowska J (2019) Reactive oxygen species (ROS) in macrophage activation and function in diabetes. Immunobiology 224: 242-253. https://doi.org/10.1016/j.imbio.2018.11.010

6. Bolduc JA, Collins JA, Loeser RF (2019) Reactive oxygen species, aging and articular cartilage homeostasis. Free Radic Biol Med 132: 73-82. https://doi.org/10.1016/j.freeradbiomed.2018.08.038

7. Dastmalchi N, Baradaran B, Latifi-Navid S, Safaralizadeh R, Khojasteh SMB, Amini M, Roshani E, Lotfinejad P (2020) Antioxidants with two faces toward cancer. Life Sci 258:118186118194. https://doi.org/10.1016/j.lfs.2020.118186

8. Irrazabal T, Thakur BK, Croitoru K, Martin A (2021) Preventing colitis-associated colon cancer with antioxidants: a systematic review. Cell Mol Gastroenterol Hepatol. https://doi.org/10.1016/j. jcmgh.2020.12.013

9. Siddeeg A, AlKehayez NM, Abu-Hiamed HA, Al-Sanea EA, ALFarga AM (2020) Mode of action and determination of antioxidant activity in the dietary sources: an overview. Saudi J Biol Sci. https:// doi.org/10.1016/j.sjbs.2020.11.064

10. Pisoschi AM, Pop A, Iordache F, Stanca L, Predoi G, Serban AI (2021) Oxidative stress mitigation by antioxidants - an overview on their chemistry and influences on health status. Eur J Med Chem 209:112891-112942. https://doi.org/10.1016/j.ejmech.2020. 112891

11. Soobrattee MA, Neergheen VS, Luximon-Ramma A, Aruoma OI, Bahorun T (2005) Phenolics as potential antioxidant therapeutic agents: mechanism and actions. Mutat Res 579:200-213. https:// doi.org/10.1016/j.mrfmmm.2005.03.023

12. Wilken R, Veena SM, Wang MB, Srivatsan ES (2011) Curcumin: a review of anticancer properties and therapeutic activity in head and 
neck squamous cell carcinoma. Mol Cancer 10:1-19. https://doi. org/10.1186/1476-4598-10-12

13. Sun C, Liu Y, Zhan L, Rayat GR, Xiao J, Jiang H, Li X, Chen K (2020) Anti-diabetic effects of natural antioxidants from fruits. Trends Food Sci Technol. https://doi.org/10.1016/j.tifs.2020.07. 024

14. Esatbeyoglu T, Huebbe P, Insa MA, DawnChin E, Wagner AE, Rimbach G (2012) Curcumin - from molecule to biological function. Angew Chem Int Ed 51:5308-5332. https://doi.org/10.1002/ anie. 201107724

15. Priyadarsini KI (2013) Chemical and structural features influencing the biological activity of curcumin. Curr Pharm Des 19:2093-2100. https://doi.org/10.2174/138161213805289228

16. Ak T, Gülcin I (2008) Antioxidant and radical scavenging properties of curcumin. Chem Biol Interact 174:27-37. https://doi.org/10. 1016/j.cbi.2008.05.003

17. Halliwell B, Murcia MA, Chirico S, Aruoma OI (1995) Free radicals and antioxidants in food and in vivo: what they do and how they work. Crit Rev Food Sci Nutr 35:7-20. https://doi.org/10. 1080/10408399509527682

18. Halliwell B (1994) Free radicals and antioxidants: a personal view. Nutr Rev 52:253-265. https://doi.org/10.1111/j.1753-4887.1994. tb01453.x

19. Lee J, Koo N, Min DB (2004) Reactive oxygen species, aging, and antioxidative nutraceuticals. Compr Rev Food Sci Food Saf 3:2133. https://doi.org/10.1111/j.1541-4337.2004.tb00058.x

20. El-Beltagi HS, Mohamed HI (2013) Reactive oxygen species, lipid peroxidation and antioxidative defense mechanism. Not Bot Horti Agrobot Cluj Napoca 41:44-57. https://doi.org/10.15835/ nbha4118929

21. Wright JS (2002) Predicting the antioxidant activity of curcumin and curcuminoids. J Mol Struct 591:207-217. https://doi.org/10. 1016/S0166-1280(02)00242-7

22. Zengin G, Degirmenci NS, Alpsoy L, Aktumsek A (2015) Evaluation of antioxidant, enzyme inhibition, and cytotoxic activity of three anthraquinones (alizarin, purpurin, and quinizarin). Hum Exp Toxicol 35:544-553. https://doi.org/10.1177/ 0960327115595687

23. Burnett AR, Thomson RH (1968) Naturally occurring quinones. Part XV. Biogenesis of the anthraquinones in Rubia tinctorum L. (Madder). J Chem Soc C:2438-2441

24. Inoue $\mathrm{K}$, Yoshida M, Takahashi M, Shibutani M, Takagi H, Hirose M, Nishikawa A (2009) Induction of kidney and liver cancers by the natural food additive madder color in a two-year rat carcinogenicity study. Food Chem Toxicol 47:184-191. https://doi.org/10. 1016/j.fct.2008.10.031

25. Rozin YA, Tatyanenko LV, Buryndina EI, Barybin AS, Popova VG (1996) Alizarin derivatives as inhibitors of calcium transport. Pharm Chem J 30:520-522. https://doi.org/10.1007/BF02334638

26. Ononye AI, Bolton JR (1986) Mechanism of the photochemistry of $p$-benzoquinone in aqueous solutions. 2. Optical flash photolysis studies. J Phys Chem 90:6270-6274

27. Jayaprakasha GK, Jagan L, Rao M, Sakariah KK (2005) Chemistry and biological activities of C. longa. Trends Food Sci Technol 16: 533-548. https://doi.org/10.1016/j.tifs.2005.08.006

28. Kumar A, Dogra S, Prakash A (2009) Protective effect of curcumin (curcuma longa), against aluminium toxicity: Possible behavioral and biochemical alterations in rats. Behav Brain Res 205:384-390. https://doi.org/10.1016/j.bbr.2009.07.012

29. Park SY, Kim DS (2002) Discovery of natural products from curcuma longa that protect cells from beta-amyloid insult: a drug discovery effort against Alzheimer's disease. J Nat Prod 65:12271231. https://doi.org/10.1021/np010039x

30. Priyadarsini KI (2014) The chemistry of curcumin: from extraction to therapeutic agent. Molecules 19:20091-20112. https://doi.org/ 10.3390/molecules191220091
31. Khan MA, Gahlot S, Majumdar S (2012) Oxidative stress induced by curcumin promotes the death of cutaneous t-cell lymphoma (HuT-78) by disrupting the function of several molecular targets. Mol Cancer Ther 11:1873-1883. https://doi.org/10.1158/15357163.MCT-12-0141

32. Kang J, Chen J, Shi Y, Jia J, Zhang Y (2005) Curcumin-induced histone hypoacetylation: the role of reactive oxygen species. Biochem Pharmacol 69:1205-1213. https://doi.org/10.1016/j.bcp. 2005.01.014

33. Wang YJ, Pan MH, Cheng AL, Lin LI, Ho YS, Hsieh CY, Lin JK (1997) Stability of curcumin in buffer solutions and characterization of its degradation products. J Pharm Biomed Anal 15:1867-1876. https://doi.org/10.1016/s0731-7085(96)02024-9

34. Masuda T, Hidaka K, Shinohara A, Maekawa T, Takeda Y, Yamaguchi H (1999) Chemical studies on antioxidant mechanism of curcuminoid: analysis of radical reaction products from curcumin. J Agric Food Chem 47:71-77. https://doi.org/10.1021/ jf9805348

35. Rege SA, Arya M, Momin SA (2019) Structure activity relationship of tautomers of curcumin: a review. Ukr Food J 8:45-60. https:// doi.org/10.24263/2304-974X-2019-8-1-6

36. Schneider C, Gordon ON, Edwards RL, Luis PB (2015) Degradation of curcumin: from mechanism to biological implications. J Agric Food Chem 63:7606-7614. https://doi.org/10.1021/ acs.jafc. 5 b00244

37. Gordon ON, Luis PB, Sintim HO, Schneider C (2015) Unraveling curcumin degradation. Autoxidation proceeds through spiroepoxide and vinylether intermediates en route to the main bicyclopentadione. J Biol Chem 290:4817-4828. https://doi.org/ 10.1074/jbc.M114.618785

38. Gordon ON, Schneider C (2012) Vanillin and ferulic acid: not the major degradation products of curcumin. Trends Mol Med 18:361364. https://doi.org/10.1016/j.molmed.2012.04.011

39. Tonnesen HH, Arrieta AF, Lerner D (1995) Studies on curcumin and curcuminoids. Part XXIV. Characterization of the spectroscopic properties of the naturally occurring curcuminoids and selected derivatives. Pharmazie 50:689-693

40. Khopde SM, Priyadarsini KI, Venkatesan P, Rao MN (1999) Free radical scavenging ability and antioxidant efficiency of curcumin and its substituted analogue. Biophys Chem 80:85-91. https://doi. org/10.1016/s0301-4622(99)00070-8

41. Sreejayan N, Rao MN (1996) Free radical scavenging activity of curcuminoids. Arzneimittelforsch 46:169-171

42. Jovanovic SV, Steenken S, Boone CW, Simic MG (1999) H-atom transfer is a preferred antioxidant mechanism of curcumin. J Am Chem Soc 121:9677-9681. https://doi.org/10.1021/ja991446m

43. Santos-Sánchez NF, Salas-Coronado R, Valadez-Blanco R, Hernández-Carlos B, Guadarrama-Mendoza PC Natural antioxidant extracts as food preservatives. Acta Sci Pol Technol Aliment 16(2017):361-370. https://doi.org/10.17306/J.AFS.2017.0530

44. Wang L, Yang F, Zhao X, Li Y (2019) Effects of nitro- and aminogroup on the antioxidant activity of genistein: a theoretical study. Food Chem 275:339-345. https://doi.org/10.1016/j.foodchem. 2018.09.108

45. Hassanzadeh K, Akhtari K, Hassanzadeh H, Zarei SA, Fakhraei N, Hassanzadeh K (2014) The role of structural C-H compared with penolic $1 \mathrm{OH}$ sites on the antioxidant activity of oleuropein and its derivatives as a great non-flavonoid family of the olive components: a DFT study. Food Chem 164:251-258. https://doi.org/10.1016/j. foodchem.2014.05.015

46. Jeremić S, Filipović N, Peulić A, Marković Z (2014) Thermodynamical aspect of radical scavenging activity of alizarin and alizarin red S. Theoretical comparative study. Comp Theor Chem 1047:15-21. https://doi.org/10.1016/j.comptc.2014.08.007

47. Marković Z, Jeremić S, Dimitrić Marković J, Stanojević Pirković M, Amic D (2016) Influence of structural characteristics of 
substituents on the antioxidant activity of some anthraquinone derivatives. Comp Theor Chem 1077:25-31. https://doi.org/10.1016/ j.comptc.2015.10.004

48. Slavova-Kazakova AK, Angelova SE, Veprintsev TL, Denev P, Fabbri D, Dettori MA, Kratchanova M, Naumov VV, Trofimov AV, Vasil'ev RF, Delogu G, Kancheva VD (2015) Antioxidant potential of curcumin-related compounds studied by chemiluminescence kinetics, chain-breaking efficiencies, scavenging activity (ORAC) and DFT calculations. Beilstein J Org Chem 11:13981411. https://doi.org/10.3762/bjoc.11.151

49. Gogoi A, Navgire M, Sarmaa KC, Gogoi P (2017) Novel highly stable b-cyclodextrin fullerene mixed valent Fe-metal framework for quick Fenton degradation of alizarin $†$. RSC Adv 7:4037140382. https://doi.org/10.1039/c7ra06447k

50. Zhu C, Jiang C, Chen S, Mei R, Wang X, Cao J, Ma L, Zhou B, Wei Q, Ouyang G, Yu Z, Zhou K (2018) Ultrasound enhanced electrochemical oxidation of alizarin red $\mathrm{S}$ on boron doped diamond(BDD) anode: effect of degradation process parameters. Chemosphere 209:685-695. https://doi.org/10.1016/j. chemosphere.2018.06.137

51. Frisch MJ, Trucks GW, Schlegel HB, Scuseria GE, Robb MA, Cheeseman JR et al (2010) Gaussian 09. Revision C.01. Gaussian Inc., Wallingford

52. Zhao Y, Truhlar DG (2008) The M06 suite of density functionals for main group thermochemistry, thermochemical kinetics, noncovalent interactions, excited states, and transition elements: two new functionals and systematic testing of four M06-class functionals and 12 other functionals. Theor Chem Acc 120:215-241. https://doi.org/10.1007/s00214-007-0310-x

53. Schaefer A, Huber C, Ahlrichs R (1994) Fully optimized contracted Gaussian-basis sets of triple zeta valence quality for atoms $\mathrm{Li}$ to $\mathrm{Kr}$. J Chem Phys 100:5829-5835. https://doi.org/10.1063/1.467146
54. Marenich AV, Cramer CJ, Truhlar DG (2009) Universal solvation model based on solute electron density and a continuum model of the solvent defined by the bulk dielectric constant and atomic surface tensions. J Chem Phys B 113:6378-6396. https://doi.org/10. $1021 /$ jp $810292 n$

55. Manolova Y, Deneva V, Antonov L, Drakalska E, Momekova D, Lambov N (2014) The effect of the water on the curcumin tautomerism: a quantitative approach. Spectrochim Acta A 132:815-820. https://doi.org/10.1016/j.saa.2014.05.096

56. Pietra F (1973) Seven-membered conjugated carbo- and heterocyclic compounds and their homoconjugated analogs and metal complexes. Synthesis, biosynthesis, structure, and reactivity. Chem Rev 73:293-364. https://doi.org/10.1021/cr60284a002

57. Liu N, Song W, Schienebeck CM, Zhang M, Tang W (2014) Synthesis of naturally occurring tropones and tropolones. Tetrahedron 70:9281-9305. https://doi.org/10.1016/j.tet.2014.07. 065

58. Jankun J, Wyganowska-Światkowska M, Dettlaff K, Jelinska A, Surdacka A, Watróbska-Świetlikowska D, Skrzypczak-Jankun E (2016) Determining whether curcumin degradation/condensation is actually bioactivation (review). Int J Mol Med 37:1151-1158. https://doi.org/10.3892/ijmm.2016.2524

59. Pirillo S, Einschlag FSG, Rueda EH, Ferreira ML (2010) Horseradish peroxidase and Hematin as biocatalysts for alizarin degradation using hydrogen peroxide. Ind Eng Chem Res 49: 6745-6752. https://doi.org/10.1021/ie901528y

60. Kornblum N, DeLaMare HE (1951) The base catalyzed decomposition of a dialkyl peroxide. J Am Chem Soc 73:880-881

Publisher's note Springer Nature remains neutral with regard to jurisdictional claims in published maps and institutional affiliations. 